\title{
LAERE
}

MIDDEL ODK

\section{Danskfaget i spil på læringsplatforme}

Af Jens Jørgen Hansen, Syddansk Universitet og Stig Toke Gissel, UCL Erhvervsakademi og Professionshøjskole

Korrekt citering af denne artikel efter APA-systemet (American Psychological Association System, 6th Edition): Hansen, J. J. \& Gissel, S. T. (2019). Danskfaget i spil på læringsplatforme. Learning Tech - Tidsskrift for læremidler, didaktik og teknologi, (6), 176-199. DOI 10.7146/lt.v4i6.110884 


\section{Abstract}

I denne artikel undersøger vi dansklæreres brug af læringsplatformen Meebook i forhold til at designe danskfaglige forløb. Forløbene har vi analyseret ud fra en fagdidaktisk analysetilgang, hvor vi både ser på funktion, form og især indhold i de didaktiske forløb. Herigennem belyser vi bl.a., hvilket danskfag og danskdidaktiske diskurser der tegner sig, og hvad der karakteriserer de danskfaglige forløb herunder forløbenes didaktiseringsgrad, inddragelse af forskellige typer læremidler, og hvem forløbene henvender sig til.

In this article we study Danish L1 teachers' use of the learning management system Meebook in relation to designing courses for Danish L1 teaching. The courses are analyzed from a subjectdidactic approach in which we look at both function, form, and, in particular, content in the L1-courses. Through this analysis we shed light on which L1 subject and which Danish L1 discourses appear in teachers' work. Furthermore, we describe what characterizes the L1 courses in relation to their degree of didactization, their inclusion of learning resources, and who the intended recipient of each course may have been. 


\section{Danskfaget i spil på læringsplatforme}

\section{Fagdidaktisk analyse af danskfaglige undervisningsforløb}

\section{Indledning}

Læringsplatforme sætter en ny kontekst for dansklæreres planlægning af undervisning og etablering af læringsrum i danskundervisningen. Det indebærer, som professor Ellen Krogh siger: "Når et fag bringes ind i nye kontekster, betyder det at fagene må formidles og kommunikeres, diskutere og legitimere sig." (Krogh, 2011, s. 39). Lærernes arbejde med at fremstille undervisningsforløb afspejler både, hvordan lærere forstår danskfaget, og hvordan de praktiserer og gør danskfaget. Gennem forløbene kan man iagttage, hvordan dansklærere positionerer danskfaget og danskundervisningen med læringsplatforme som kontekst. De forskellige forløb peger på en særlig fagdidaktisk kultur, dvs. fælles forestillinger om hvad danskfaget er, og hvordan faget kan praktiseres i den nye kontekst, som en læringsplatform udgør.

Forskningsspørgsmålet for denne artikel er således tofoldigt: For det første er intentionen at beskrive og kortlægge, hvordan dansklærere bruger læringsplatforme som didaktisk redskab, dvs. hvilke typer fagdidaktiske design, kan vi se, at lærerne producerer? For det andet er vi interesserede i at undersøge, hvilket fagsyn og versioner af danskfaget disse fagdidaktiske design er funderet på, herunder hvorvidt læringsplatforme som didaktisk kontekst har potentiale til at udvikle nye faglige didaktiske design og innovativ undervisning. Vores forståelse af danskfagets fagsyn knytter an til positionerne: dansk som basisfag, identitetsfag, kreativitetsfag og kommunikationsfag.

\section{Forløbsbyggeren i Meebook}

Forløbsbyggeren i læringsplatformen Meebook indeholder redskaber til at bygge forløb op, element for element. Affordanserne i forløbsbyggeren er centrale for at forstå, hvorfor forløbene i Meebook er designet, som de er. 


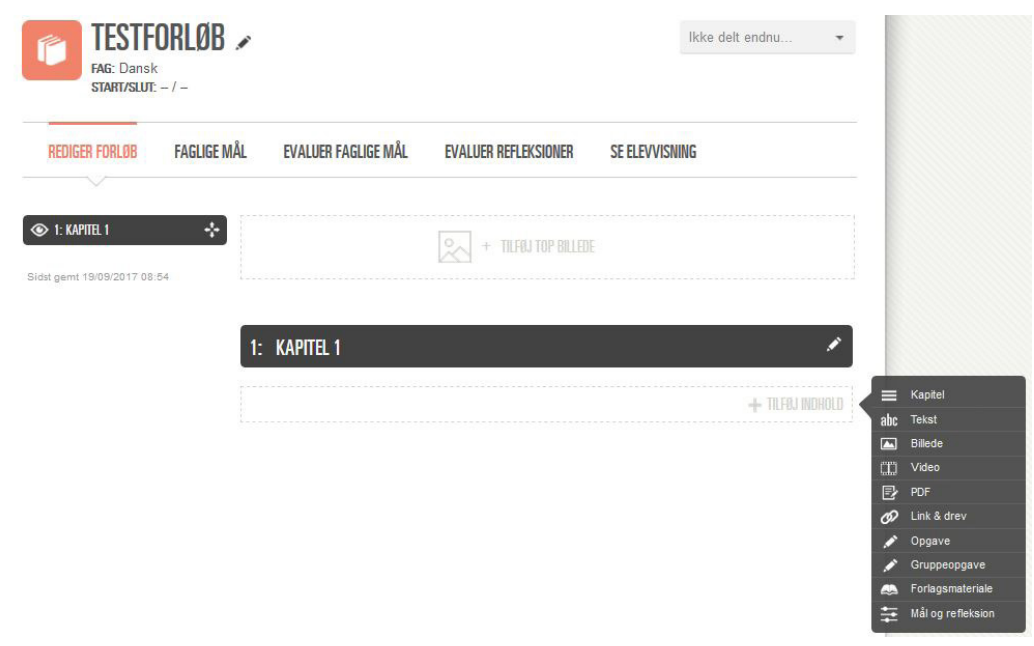

Når brugeren skal designe et forløb, mødes man af den brugerflade, som ses i Figur 1. Der er en arbejdsflade, hvor brugeren kan indsætte kapitler og blokke med forskellige typer indhold: Tekst, faste billeder, video, PDF-filer samt links til fx Google Drive. Ydermere er der en funktion til at oprette opgaver, gruppeopgaver, forlagsproducerede læremidler og en funktion til evaluering. Læreren har fuld frihed til at kombinere disse elementer efter $\emptyset n s k e$. Fx kan læreren indsætte en evaluering først i forløbet (fx med henblik på, at eleverne selvevaluerer deres forudsætninger i forhold til et faglige område), undervejs eller sidst i forløbet.

\section{Metode}

Formålet med den fagdidaktiske analyse er på den korte bane at kortlægge mønstre for didaktiseringer af fag og undervisning i læringsplatformen. Sigtet er på længere sigt at bidrage med viden om, hvordan danskfagets didaktiske praksis kan udvikles. Perspektivet er således fagudvikling som en særlig forskningsinteresse.

Undersøgelsens empiri består af de 37 hyppigst downloadede danskfaglige forløb som vi kan iagttage i læringsplatformen Meebook den 18. august 2017. Empirien kan karakteriseres som internetressourcer og didaktiske dokumenter, som hverken er produceret af os som undersøgere eller er produceret til unders $\emptyset$ - 
gelse. Grundlæggende har dokumenter en ontologisk status, der afspejler en konkret virkelighed, men samtidig er de også skrevet med et konkret formål - og bør ses i en større sammenhæng. Dokumenter kan ses som sociale facts eller konstruktioner:

99

Documents can tell us a lot about a social setting or an individual life. However, we have to approach the analysis of documents for what they are and for what they are used to accomplish. This means paying attention to the knowledge that documents 'contain' about a setting, but also examining their role and place in settings, the cultural values attached to them, their distinctive types and forms.

(Coffey, 2014, s. 372)

For at forstå de didaktiske design må vi også se dem i forhold til den konkrete kontekst, de er produceret og bruges i. Her går vi ikke helt ned i den enkelte lærers kontekst, men ser de didaktiske dokumenter som repræsentationer af en typisk kontekst for planlægning af forløb i læringsplatforme.

Vores tilgang til de didaktiske design er at de repræsenterer en underliggende faglig forestilling og praksis hos de konkrete lærere, som igen repræsenterer dansklærere som en gruppe i skolen. De didaktiske design fortæller således om, hvordan lærere tænker fag, hvordan de tænker læringsplatforme, og hvordan de tænker undervisning, og kan ses som et udtryk for en underliggende fagkulturs tilgang til brug af læringsplatforme.

Vores fagdidaktiske analyse af forløbene sker med udgangspunkt i den fagdidaktiske analysemodel med fokus på didaktiske designs form, funktion og indhold (Hansen, 2018): 


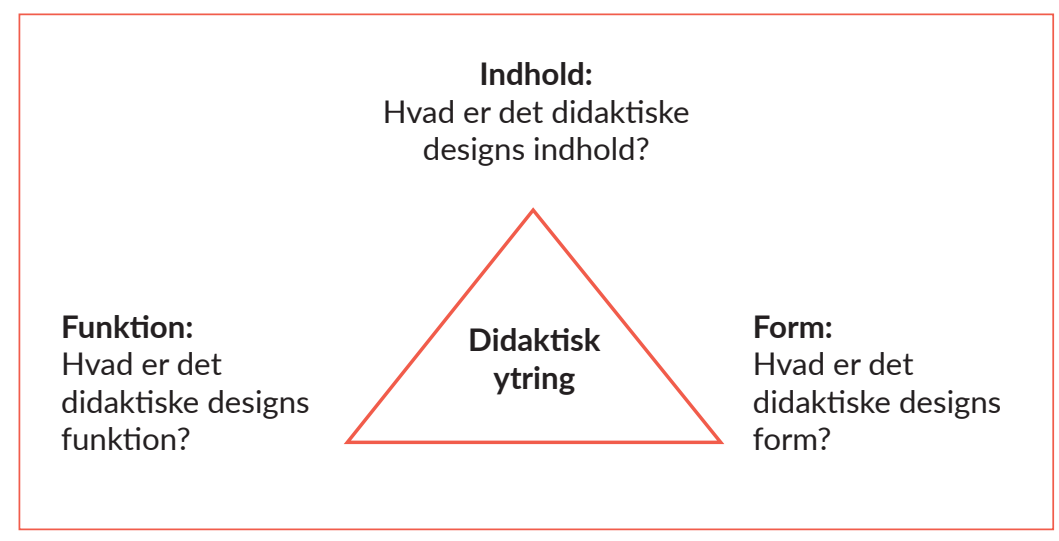

Modellen tager udgangspunkt $i$, at en didaktisk ytring, fx planlægning af et undervisningsforløb eller et didaktisk design, rummer tre aspekter: En indholdsside (et didaktisk design handler om noget), en formside (et didaktisk design har en særlig form) og en funktionsside (det didaktiske design indgår i en brugssituation, en række aktiviteter og handlinger). Bevægelsen fra at fokusere på forløbenes funktion, form og siden indhold gør, at vi gennem artiklen kan identificere de forløb, der afspejler planlægning, der er relativt højt didaktiseret og didaktisk struktureret, og se på, hvilke aspekter af danskfaget forløbene aktualiserer.

\section{Didaktisk design som funktion}

De didaktiske design er tekster som er skabt til at 'gøre noget', dvs. de indgår i en kæde af aktiviteter, der kan have forskellige funktioner og modtagere. Vi vil i vores analyse undersøge de didaktiske designs funktioner ud fra to perspektiver:

- Planlægningsaktivitet med eleverne som modtagere, og hvor læreren reflekterer over, hvad et forløb skal handle om, og hvad eleverne skal lære og gøre.

- Videndelingsaktivitet med andre kollegaer som modtagere, og hvor læreren reflekterer over, hvordan udviklingen af didaktiske design kan inspirere andre undervisere til at udvikle deres praksis. 
Operationaliseringen af denne kategori består i, at vi har identificeret, hvem forløbet som talehandling er rettet mod ud fra brugen af stedord, og holdt dette op mod karakteren af den handling, som modtageren skal udføre: Drejer handlingerne sig om tilrettelæggelse eller gennemførelse af undervisning eller om læringsaktiviteter?

Tabel 1. Forløb rettet mod elever eller kolleger.

\begin{tabular}{|c|c|c|}
\hline & Indikatorer & Eksempler \\
\hline $\begin{array}{l}\text { Forløb rettet til } \\
\text { elev(er)/klassen }\end{array}$ & $\begin{array}{l}\text { Brug af stedord: Eleven tiltales i } \\
\text { 2. person ental (du), elever tiltales } \\
\text { i 2. person flertal (I) eller klassen } \\
\text { tiltales i 1. person flertal (vi). } \\
\text { Aktiviteten angår læringsaktiviteter. }\end{array}$ & $\begin{array}{l}\text { "Før vi går i gang, kigger vi lige på } \\
\text { vores brainstorms-film..." } \\
\text { "Start med at tænke over, hvad du } \\
\text { allerede kan og ved om emnet." } \\
\text { Begge eksempler fra forløbet } \\
\text { "H.C. Andersen", 2. klasse. }\end{array}$ \\
\hline $\begin{array}{l}\text { Forløb rettet til } \\
\text { kolleger }\end{array}$ & $\begin{array}{l}\text { Brug af stedord: Læreren tiltales i } \\
\text { 2. person ental (du), og/eller } \\
\text { eleverne/klassen tiltales ikke } \\
\text { direkte. Aktiviteter angår plan- } \\
\text { lægnings-, tilrettelæggelses- eller } \\
\text { undervisningsaktiviteter. }\end{array}$ & $\begin{array}{l}\text { "Opgaverne er tænkt til slut } \\
\text { 2. klasse begyndelse af 3. klasse." } \\
\text { "Opgaverne printes som } \\
\text { tosidet-kopi." } \\
\text { Begge eksempler fra forløbet } \\
\text { "Frøken Ignora". }\end{array}$ \\
\hline
\end{tabular}

\section{Didaktisk design som form}

Didaktisk design som form analyseres ud fra begrebet didaktiseringsgrad. Didaktiseringsgrad handler om, i hvor høj grad didaktiske design integrerer didaktiske elementer: Didaktiske design med en høj didaktiseringsgrad indeholder både mål, indhold, metoder og aktiviteter, og en grad af sammenhæng mellem disse, hvorimod didaktiske design med en lav didaktiseringsgrad fx kun peger indhold og aktiviteter ud. Forløbet med lav didaktiseringsgrad udgør således ikke en integreret, didaktisk struktur, hvor der er sammenhæng mellem mål, indhold, metoder og aktiviteter, men udgør en disparat struktur, hvor de forskellige didaktiske elementer tilfældigt er ophobet og ikke støtter hinanden i forhold til at skabe en klar struktur i designet. 


\begin{tabular}{|c|c|c|}
\hline & Indikatorer & Eksempel \\
\hline $\begin{array}{l}\text { Høj } \\
\text { didaktiseringsgrad }\end{array}$ & $\begin{array}{l}\text { Forløbet indeholder og integrerer } \\
\text { mål, indhold, metoder og } \\
\text { aktiviteter. }\end{array}$ & $\begin{array}{l}\text { Som en del af forløbet "Lyrik" } \\
\text { præsenteres eleverne for en film } \\
\text { med Tove Ditlevsens biografi. } \\
\text { Herefter skal eleverne læse digtet } \\
\text { "Så tag mit hjerte". Bagefter skal } \\
\text { eleverne gøre rede for, hvad } \\
\text { digtet handler om og sidenhen } \\
\text { overveje "Hvordan passer digtet } \\
\text { ind i Tove Ditlevsens liv?" Der er } \\
\text { sammenhæng mellem mål, metode, } \\
\text { indhold og aktiviteter. }\end{array}$ \\
\hline $\begin{array}{l}\text { Lav } \\
\text { didaktiseringsgrad }\end{array}$ & $\begin{array}{l}\text { Forløbet består af aktiviteter og } \\
\text { indholdselementer uden eller med } \\
\text { lav didaktisk rammesætning og } \\
\text { sammenhæng. }\end{array}$ & $\begin{array}{l}\text { I forløbet "Navneord" skal eleverne } \\
\text { igennem samme cyklus flere } \\
\text { gange: Se en video (indhold), fx om } \\
\text { hvad navneord er, udføre et par } \\
\text { aktiviteter, fx "Skriv de } 5 \text { navneord } \\
\text { fra teksten" og evaluere, fx "Jeg } \\
\text { ved hvad navnerod er". Der er } \\
\text { ikke sammenhæng mellem mål, i } \\
\text { dette tilfælde "Eleven har viden } \\
\text { om ord og udtryk i instruktioner } \\
\text { og opgaver", metode, indhold og } \\
\text { aktiviteter. }\end{array}$ \\
\hline
\end{tabular}

\section{Didaktisk design som indhold}

Et didaktisk design afspejler lærerens forståelse af fag og undervisning. I en danskfaglig analyse kan man analysere didaktiske design i forhold til, hvordan lærere forstår et fag. Danskfaget kan fx forstås som et fag, der sigter mod at udvikle elevernes tolkende og betydningsskabende kompetence, deres skabende kompetence, deres kommunikative kompetence eller grundlæggende socialisere dem ind i en forståelse af sprog og tekster. En fagdidaktisk analyse undersøger, hvilke fagdidaktiske valg en lærer foretager i forhold til at planlægge et undervisningsforløb. Vi har i denne analyse været optaget af to spørgsmål:

— Hvilke danskfaglige diskurser, kan vi se, optræder i forløbene?

— På hvilken måde integreres ressourcer i forløbene? 
Diskurser er en tilgang til at forstå læreres fagforståelse. Gee (1990) definerer diskurser som:

99

[W]ays of behaving, interacting, valuing, thinking, believing, speaking and often reading and writing that are accepted as instantiations of particular roles by specific groups of people. [...] They are always and everywhere social. Language, as well as literacy, is always and everywhere integrated and relative to social practices constituting particular Discourses. (Gee, 1990, s. xix)

Danskfaglige diskurser bruges i forlængelse af Gee's definition som en analytisk optik til at undersøge, hvordan dansklærere opfatter danskfaget, dvs. som en måde at tale om og værdisætte danskfaget på som eksisterer indenfor den sociale praksis, som undervisning og lærerprofessionen udgør. Dansklærere har som permanent opgave at fortolke og udmønte, hvad der er væsentligt i danskfaget, og konstruerer således danskfaget gennem deres undervisning. Diskursanalysen kan ikke sige noget om, hvordan dansklærere eksplicit fortolker danskfaget - de er ikke blevet spurgt om, hvordan de ser danskfaget, men analysen er vores fortolkning af de mønstre, vi ser i lærernes didaktiske praksis. Analysen bygger således på en oversættelse af dansklærernes manifestationer af deres didaktiske praksis og deres arbejde med at designe og opbygge læringsforløb gennem læringsplatformen som medie.

Teoretisk er diskursanalysen funderet i de fire fagdiskurser som præsenteres i bogen Dansk som undervisningsfag: dansk som identitetsfag, kommunikationsfag, kreativt fag og basisfag (Hansen, 2012). De fire fagdiskurser udpeger forskellige måder at forstå danskfaget på, og der kan findes legitimation for hver af diskurserne i fagformålet for danskfaget. Den enkelte diskurs udpeger endvidere bestemte kompetencer, som eleven tænkes at tilegne sig, bestemte sagområder og bestemte aktiviteter. De fire fagdiskurser tager udgangspunkt $i$, at danskfaget er et tekstfag, hvor tekster udgør den stoflige kerne, hvoraf forskellige kompetencer former sig: "Danskfagets særlige opgave er at lære eleverne reflekteret og bevidst at omgås tekster. De skal i undervisningen opleve tekster, lege med tekster, undersøge tekster, forstå tekster, læse tekster, lade sig inspirere, provokere og 
vurdere tekster" (Hansen, 2012, s. 13). Danskfagets arbejde med tekster kan udledes af fagets fagformål:

Stk. 1. Eleverne skal i faget dansk fremme deres oplevelse og forståelse af litteratur og andre æstetiske tekster, fagtekster, sprog og kommunikation som kilder til udvikling af personlig og kulturel identitet. Faget skal fremme elevernes indlevelsesevne og deres æstetiske, etiske og historiske forståelse.

Stk. 2. Eleverne skal i faget dansk styrke deres beherskelse af sproget og fremme deres lyst til at bruge sproget personligt og alsidigt i samspil med andre. Eleverne skal udvikle en åben og analytisk indstilling til samtidens og andre perioders og kulturers udtryksformer. Eleverne skal i faget dansk udvikle deres udtryksog læseglæde og kvalificere deres indlevelse og indsigt i litteratur og andre æstetiske tekster, fagtekster, sprog og kommunikation.

Stk. 3. Eleverne skal i faget dansk have adgang til de skandinaviske sprog og det nordiske kulturfællesskab.

Dansk som identitetsfag relaterer til teksters rolle som "kilder til udvikling af personlig og kulturel identitet", og som dermed kan "fremme elevernes indlevelsesevne og deres æstetiske, etiske og historiske forståelse". Teksters særlige potentiale som kilder til identitet er, at tekster i kraft af deres formsprog, deres indhold og bestemte livsbilleder kan engagere eleverne og muliggøre udvikling af deres æstetiske, etiske og historiske referencer. Det er især litterære tekster, der kan åbne elevers øjne for teksternes perspektiver. Gennem arbejdet med tekster er målet endvidere at styrke elevernes hermeneutiske teksttolkning, dvs. oplevelse af samt greb og begreb om teksters æstetik, etik og historie.

Tabel 3. Danskfaglig diskurs: Identitetsfag.

\begin{tabular}{|c|c|c|}
\hline $\begin{array}{l}\text { Danskfaglig } \\
\text { diskurs }\end{array}$ & Indikatorer & Eksempel \\
\hline Identitetsfag & $\begin{array}{l}\text { Tekster anvendes på måder der } \\
\text { kan styrke elevernes identitets- } \\
\text { dannelse, æstetiske, etiske og } \\
\text { historiske referencer og herme- } \\
\text { neutiske teksttolkning. }\end{array}$ & $\begin{array}{l}\text { I forløbet "Kim Fupz Aakeson" } \\
\text { skriver læreren i den indledende } \\
\text { rammesætning: "Vi skal arbejde } \\
\text { med forfatterens sprog, skrivemåde } \\
\text { og især hans sjove moraler." }\end{array}$ \\
\hline
\end{tabular}


Dansk som kommunikationsfag handler om, at danskfaget kan styrke elevers "beherskelse af sproget og fremme deres lyst til at bruge sproget personligt og alsidigt i samspil med andre", som det formuleres i formålet. Eleverne skal her udvikle kommunikative kompetencer til at kommunikere med og gennem tekster samt lære at deltage i kommunikative situationer, hvor der debatteres, udveksles holdninger og skabes mening og betydning.

Tabel 4. Danskfaglig diskurs:

Kommunikationsfag.

\begin{tabular}{l|l|l}
$\begin{array}{l}\text { Danskfaglig } \\
\text { diskurs }\end{array}$ & Indikatorer & $\begin{array}{l}\text { Eksempel } \\
\text { Kommunika- } \\
\text { tionsfag }\end{array}$ \\
& $\begin{array}{l}\text { Der er fokus på at styrke elevernes } \\
\text { kommunikative kompetence. }\end{array}$ & $\begin{array}{l}\text { I forløbet "Faste reklamer" } \\
\text { præsenteres eleverne for følgende } \\
\text { opgave efter at være blevet } \\
\text { undervist om forskellige aspekter } \\
\text { af genren: "Find en god idé til jeres } \\
\text { reklame. Det er vigtigt at finde ud } \\
\text { af, hvilket produkt, I vil reklamere } \\
\text { for. Find målgruppe og lav et godt } \\
\text { billede. Husk slogan og tekst. } \\
\text { Brug Minervamodellen." }\end{array}$ \\
&
\end{tabular}

Dansk som kreativitetsfag handler om, at danskfaget kan styrke elevernes skabende kompetencer og deres "udtryksglæde". Eleverne skal her lære at skabe tekster og styre skrive- og fremstillingsprocesser fra idé til færdig tekst. 


\begin{tabular}{l|l|l}
$\begin{array}{l}\text { Danskfaglig } \\
\text { diskurs }\end{array}$ & Indikatorer & Eksempel \\
\hline Kreativitetsfag & $\begin{array}{l}\text { Der er fokus på at styrke elevernes } \\
\text { skabende kompetencer og udtryks- } \\
\text { glæde gennem tekstproduktion. }\end{array}$ & $\begin{array}{l}\text { I forløbet "Helte" indgår følgende } \\
\text { opgave: "Lav to animationsfilm. } \\
\text { Brug fx Puppet Pals eller Go Ani- } \\
\text { mate. } \\
\text { Den ene film skal være et eksempel } \\
\text { på en hverdagshelt. } \\
\text { Den anden film skal være et eksem- } \\
\text { pel på en superhelt." }\end{array}$
\end{tabular}

Dansk som basisfag handler om, at danskfaget kan styrke elevernes "beherskelse af sproget" og støtte deres udvikling af en "åben og analytisk indstilling til samtidens og andre perioders og kulturers udtryksformer." Målet er at styrke elevernes grundlæggende tekst- og sprogkompetencer, fx grammatik, stavning, genrekendskab og grundlæggende færdigheder i at læse, skrive, lytte og tale.

Tabel 6. Danskfaglig diskurs: Basisfag.

\begin{tabular}{l|l|l}
$\begin{array}{l}\text { Danskfaglig } \\
\text { diskurs }\end{array}$ & Indikatorer & $\begin{array}{l}\text { Eksempel } \\
\text { Basisfag }\end{array}$ \\
\hline $\begin{array}{l}\text { Der er fokus på at styrke elevernes } \\
\text { krundlæggende tekst- og sprog- } \\
\text { kompetence. }\end{array}$ & $\begin{array}{l}\text { I forløbet "Stavning og grammatik" } \\
\text { er der bl.a. følgende læringsmål: } \\
\text { "Stavning og grammatik } \\
\text { Du skal lære at skelne mellem } \\
\text { ordklasserne substantiver i bestemt } \\
\text { flertal og verber i lang tillægsform. } \\
\text { Du skal styrke dine stave- } \\
\text { færdigheder." Forløbet indeholder } \\
\text { aktiviteter med træning af bøjning } \\
\text { af ordklasser, endelser mv. }\end{array}$ \\
\hline
\end{tabular}




\section{Danskfag og danskundervisning på læringsplatformen Meebook}

I det følgende redegør vi for resultaterne af vores analyse på grundlag af de tre analyseniveauer: didaktiske designs funktion, indhold og form. Graf, Gissel og Slot (2018) analyserede på tværs af fag 102 forløb i Meebook. Vores empiri udgør de 37 af disse 102 forløb, som er skabt til danskfaget (Tabel 1). Dermed giver det god mening at se, om der er mønstre i den måde, platformen anvendes på i forhold til et bestemt fag, når dette stilles over for anvendelse i en bred vifte af andre fag.

Tabel 7. Antal analyserede forløb i dansk og andre fag samt procentvis fordeling på trin.

\begin{tabular}{l|l|l|} 
& Dansk & Andre fag end dansk \\
\hline Indskoling & $41 \%$ & $29 \%$ \\
Mellemtrin & $30 \%$ & $35 \%$ \\
Udskoling & $30 \%$ & $35 \%$ \\
I alt - antal forløb & 37 & 65 \\
\hline
\end{tabular}

\section{Didaktiske design som funktion og form}

Af de 37 forløb er de 35 forløb designet til en konkret undervisningssituation med eleverne som modtagere. Med andre ord er planlægningsfunktionen central i størstedelen af forløbene. Men interessant er det, at 11 af de 35 forløb henvender sig til både elever og lærere, dvs. at planlægnings- og videndelingsfunktion overlapper (se Figur 1). 
Figur 3. Forholdet mellem brugen af platformen i forhold til de didaktiske designs funktion og form.

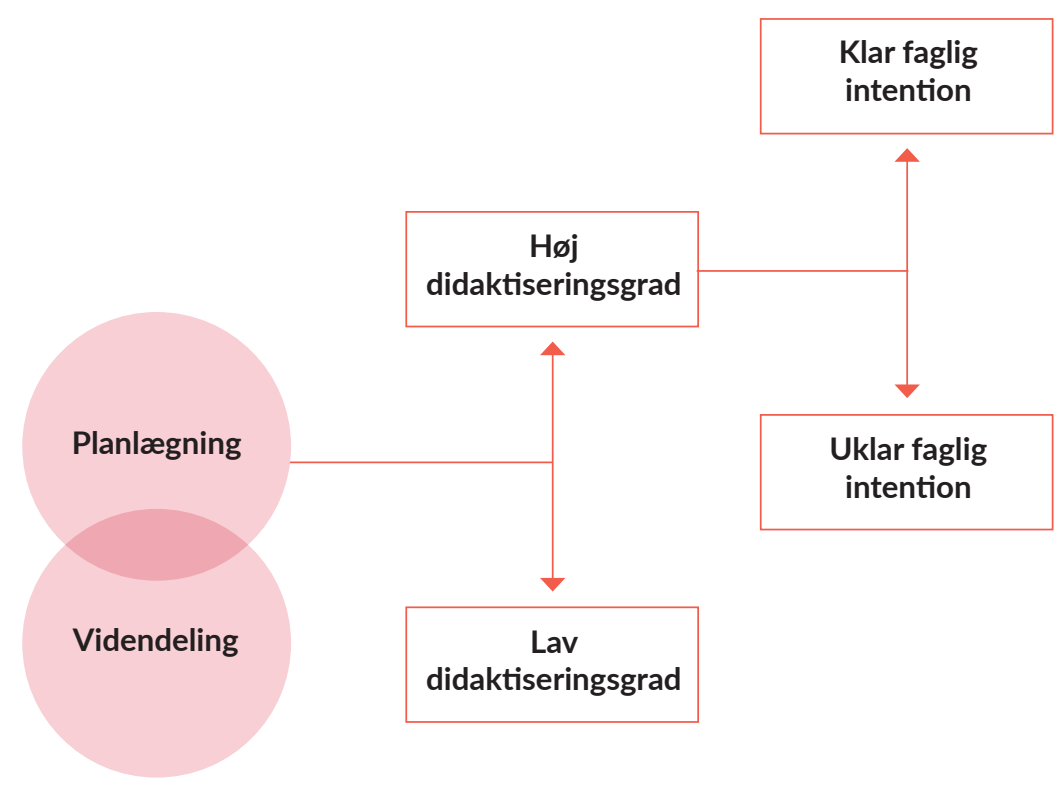

Hvis en lærer vil metakommunikere til andre lærere på Meebook, så kan læreren lave en generel beskrivelse af forløbet, som kan tilgås i forløbsoversigten. Men Meebook har ikke en funktionalitet, hvor lærere kan metakommunikere inde i selve forløbet, fx om specifikke elementer i forløbet. Derfor finder lærerne forskellige løsninger på denne udfordring. Fx ser vi flere eksempler på, at lærere skjuler elementer i forløbene, så de kun kan ses i forløbsbyggeren af andre lærere, men ikke af eleven (Figur 4). 
Figur 4. Læreren har skjult informationerne til andre lærere om forløbets opbygning, så de kun kan ses i forløbsbyggeren. Boksen med læringsmål er derimod synlig for eleven.

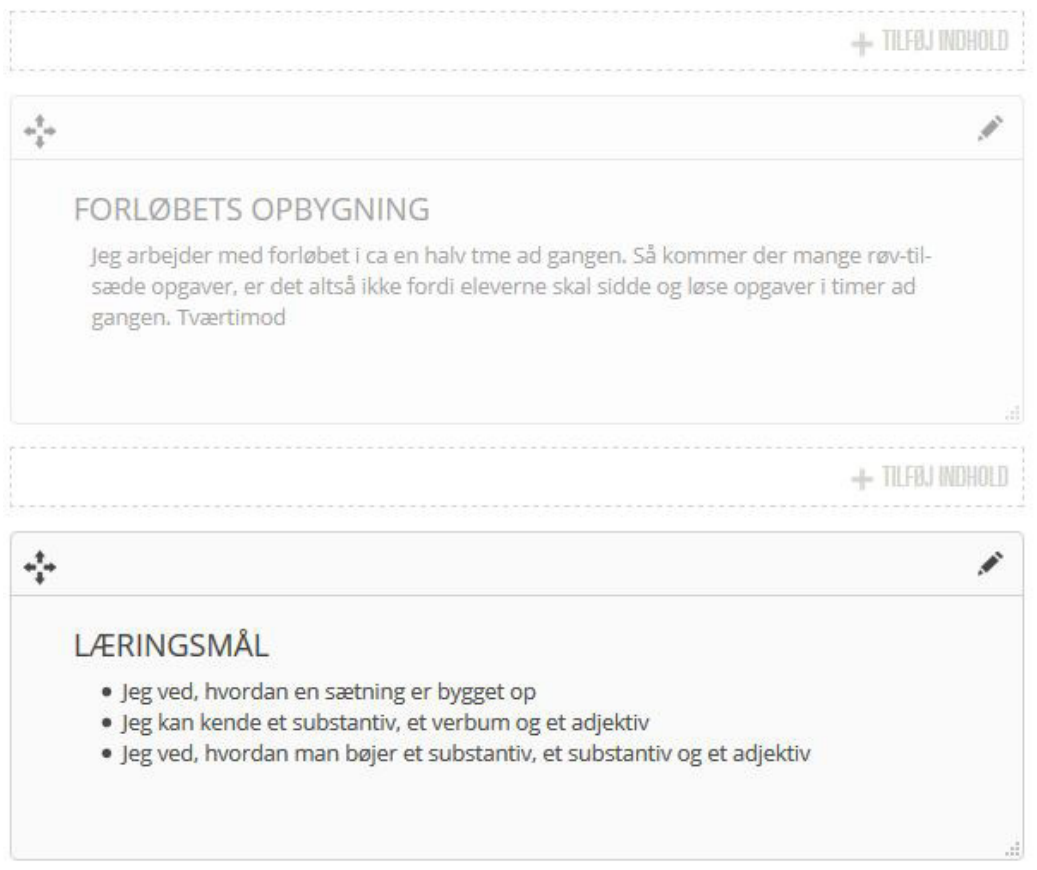

Ét af de 35 forløb, "Frøken Ignora", er designet udelukkende med kollegaer som intenderet modtager, hvor Meebook kommer til at fungere udelukkende som et fildelingssystem eller et videndelingssystem. Et andet forløb, "Knæk læsekoden”, er et ufærdigt forløb, der kun henvender sig til andre lærere, ikke til elever.

En undersøgelse af formen i de didaktiske design på de 35 forløb designet med henblik på en konkret undervisningssituation viser, at halvdelen har en lav til middel didaktiseringsgrad og den øvrige halvdel har en højere didaktiseringsgrad. Den lavere didaktiseringsgrad består i simple aktiviteter, fx et kursus ("Vokalkursus") eller læs-og-forstå-aktiviteter knyttet til et litterært forløb (fx forløbet "Pippi Langstrømpe", hvor eleverne skal læse eller får højtlæst Pippi, svare på spørgsmål og udfylde ordkort). Forløbene med højere didaktiseringsgrad deler sig igen i en halvdel med klar faglig intention og en halvdel med en uklar faglig intention. Et eksempel på et forløb med en uklar faglig 
intention er et forløb om "H.C. Andersen", hvor eleverne skal læse en kort biografi om H.C. Andersen, se en video om hans liv, læse "Fyrtøjet", svare på tre spørgsmål til teksten, vælge en scene og tegne den samt se en filmatisering af "Fyrtøjet". Der er ingen klar didaktisk integration og intention i forløbet, som består af aktiviteter under en paraply, der hedder "H.C. Andersen". Et andet forløb har en mere klar faglig intention, hvis mål er kendskab til lyrikgenren. Eleverne introduceres for lyrikgenren og faglige temaer som fx rimtyper, de møder forskellige digte og slutter forløbet med selv at skrive digte.

En anden måde at anskue didaktiseringsgrad og faglig intention på er at se på, hvordan læreren integrerer ressourcer i forløbet. Forløbene samler nemlig typisk en række ressourcer, som læreren i større eller mindre grad didaktiserer og integrerer i en samlet didaktisk struktur. Tabel 2 viser, hvilke typer læremidler der inddrages i forløb på Meebook til henholdsvis faget dansk og andre fag. Vi opererer med tre typer læremidler (Hansen, 2006; Hansen, 2010; Bundsgaard \& Hansen, 2011):

- Didaktiske loeremidler er produceret specifikt med undervisning for øje. Det didaktiske læremiddel faciliterer eller varetager en række didaktiske opgaver i undervisningen, fx faglig målsætning, formidling af fagligt indhold og rammesætning af aktiviteter og opgaver. Didaktiske læremidler er typisk udstyret med en vejledning til læreren.

- Funktionelle loeremidler er læremidler, der fungerer som redskaber og værktøjer, der faciliterer håndtering af indhold eller arbejdsprocesser i undervisningen. Eksempler er regneark, et billedredigeringsprogram eller programmet Mindmeister. At anvende sådanne værktøjer i undervisningen kræver, at læreren aktivt didaktiserer dem, da producenten oftest ikke har intenderet, at det specifikt skulle bruges til undervisning.

- Semantiske loeremidler er bærere af et givent indhold, som fungerer uden for skolens kontekst. Eksempler er en kortfilm, et digt eller et computerspil. Her er ikke indbygget en didaktisering, og læreren skal derfor aktivt didaktisere det semantiske læremiddel, før det er anvendeligt i fagundervisningen.

Analysen viser, at det især er digitale didaktiske og semantiske læremidler, der integreres i de danskfaglige forløb, og Tabel 8 
viser, at dette gælder i højere grad for danskfaget end de resterende fag. Det er markant, at digitale, semantiske læremidler anvendes hyppigere i danskfaglige forløb end i forløb til andre fag ( $57 \%$ i danskfaglige forløb mod $46 \%$ til andre fag). Dette er ikke overraskende, givet at danskfaget er et tekstfag. Desuden har de danskfaglige forløb markant flere forekomster af analoge, semantiske læremidler i forløbene. Den relativt hyppige inddragelse af analoge, didaktiske læremidler i danskfaget set i forhold til andre fag er heller ikke overraskende, set i lyset af at Bundsgaard, Buch og Fougt (2017) kom til det resultat, at det analoge system bruges hyppigt i danskfaget i især indskolingen, men også er meget udbredt på mellemtrinnet.

Tabel 8. Procentvis fordeling af forløb, hvor der findes mindst én forekomst af forskellige typer læremidler opdelt på dansk og andre fag end dansk.

\begin{tabular}{l|l|l} 
Type læremiddel & Dansk \% & Andre fag \% \\
\hline Digitalt, didaktisk læremiddel & 49 & 38 \\
\hline Digitalt, semantisk læremiddel & 57 & 46 \\
\hline Digitalt, funktionelt læremiddel & 24 & 12 \\
\hline Analogt, didaktisk læremiddel & 11 & 6 \\
\hline Analogt, semantisk læremiddel & 24 & 9 \\
\hline Analogt, funktionelt læremiddel & 3 & 3
\end{tabular}

Tabellen afspejler ikke, hvor mange af hver type læremiddel, der gennemsnitligt er i forløbene; scoringen har nemlig kun registreret første forekomst af typerne i hvert forløb. Men vi ser en klar tendens til, at der ophobes større mængder ressourcer i forløbene, ikke mindst i de lavt didaktiserede forløb. Ser vi nærmere på et af forløbene med en lav didaktiseringsgrad, "Vokalkursus", ser vi et eksempel på dette. Figur 3 viser en serie af PDF-filer, som ikke kittes sammen didaktisk i forløbet. Hver PDF viser et forslag til værksteder, hvor eleverne kan arbejde hen mod at "komme til bunds i vokalerne", som er kursets ekspliciterede mål. Forløbet indeholder i alt 17 PDF-filer, en henvisning til et forlagsproduceret digitalt, didaktisk læremiddel med tilhørende træningsopgaver samt syv evalueringsbokse. 
Figur 5. I forløbet "Vokalkursus" ser vi et eksempel på ophobning af ressourcer, som ikke integreres i en didaktisk struktur.

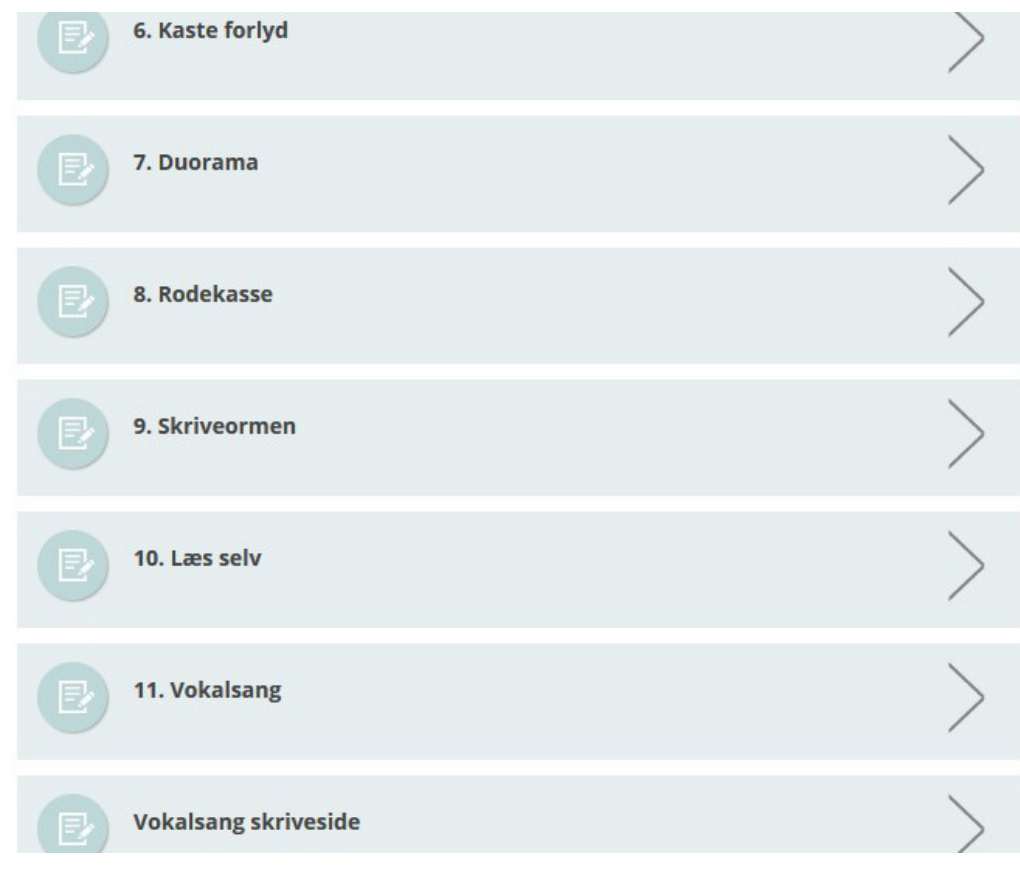

Forløbet henvender sig eksplicit til elever, som følgende indledende tekst viser: "Start med en evaluering for at finde dit udgangspunkt. Derefter skal du selv vælge værksteder, der kan få dig tættere på målene på alle tre niveauer", og eleverne positioneres, som citatet også viser, i stort omfang som didaktiske designere. Forløbet peger ressourcer ud; eleverne skal vælge de aktiviteter ud, som de mener, er passende. Spørgsmålet er dog, om det reelt er meningen, at eleverne i o.-1. klasse selv skal kunne læse denne tekst og udføre denne selvregulerede proces. Vi tænker, at andre lærere er den reelle intenderede modtager, som skal formidle instruktionerne i et mere alderssvarende sprog og stilladsere elevernes aktivitet i højere grad, end forløbet på platformen lægger op til.

Læringsplatformen kan på den ene side støtte læreren i at kommunikere forskellige faglige forløb og dermed understøtte funktionen i de didaktiske ytringer. Men kvaliteten og indholdet i de to øvrige elementer i den didaktiske ytring, formulering af indhold og udformning af en god sammenhængende didaktisk struktur er helt op til lærerens eksisterende erfaringer og didaktiske kompetence. 


\section{Didaktiske design som indhold}

De 37 hyppigst hentede Meebook-forløb til danskfaget er undersøgt i forhold til, om de fire fagdiskurser, som danskfaget kan karakteriseres ved, kommer til udfoldelse i hvert enkelt forløb. Hvis der i forløbet kunne identificeres bare én aktivitet, som lægger op til, at eleverne arbejder inden for en de fire fagdiskurser, så har forløbet fået en markering ud for fagdiskursen (9). 
Tabel 9. Tabellen viser henholdsvis titel, trin og hvorvidt, der findes aktiviteter i hvert forløb, der kan karakteriseres som henholdsvis basis-, identitets-, kreativitetsog kommunikationsdanskfaglig. Desuden viser tabellen didaktiseringsgrad og hvorvidt, der kan identificeres en klar faglig intention i de højt didaktiserede forløb.

Trin er opdelt i henholdsvis indskoling (I), mellemtrin (M) og udskoling (U).

\begin{tabular}{|c|c|c|c|c|c|c|c|}
\hline Titel på forløb & 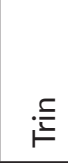 & $\begin{array}{l}\text { Basis- } \\
\text { dansk }\end{array}$ & $\begin{array}{l}\text { Iden- } \\
\text { titets- } \\
\text { dansk }\end{array}$ & $\begin{array}{l}\text { Kreati- } \\
\text { vitets- } \\
\text { dansk }\end{array}$ & $\begin{array}{l}\text { Kommu- } \\
\text { nikations- } \\
\text { dansk }\end{array}$ & $\begin{array}{l}\text { Didak- } \\
\text { tiserings- } \\
\text { grad }\end{array}$ & $\begin{array}{l}\text { Faglig } \\
\text { inten- } \\
\text { tion }\end{array}$ \\
\hline Vokalkursus & I & & & & & Lav & \\
\hline 120 Ord & I & & & & & Lav & \\
\hline Frøken Ignora & 1 & & & & & Høj & Uklar \\
\hline H.C. Andersen & 1 & & & & & Høj & Uklar \\
\hline Ordklasser & 1 & & & & & Lav & \\
\hline Knæk læsekoden & 1 & & & & & Lav & \\
\hline Folkeeventyr & 1 & & & & & Middel & \\
\hline $\begin{array}{l}\text { H.C. Andersen } 2 . \\
\text { kl. }\end{array}$ & 1 & & & & & Høj & Uklar \\
\hline Helte & 1 & & & & & Høj & Uklar \\
\hline Navneord & I & & & & & Lav & \\
\hline $\begin{array}{l}\text { Faglig læsning og } \\
\text { dyr }\end{array}$ & I & & & & & Middel & \\
\hline Pippi Langstrømpe & 1 & & & & & Middel & \\
\hline $\begin{array}{l}\text { Den første læsning } \\
\text { læsebog 2. kl. }\end{array}$ & I & & & & & Lav & \\
\hline $\begin{array}{l}\text { Grammatik i } 2 . \\
\text { klasse }\end{array}$ & I & & & & & Lav & \\
\hline $\begin{array}{l}\text { Nabosprog og } \\
\text { Astrid Lindgren - } \\
\text { Master }\end{array}$ & 1 & & & & & Høj & Klar \\
\hline $\begin{array}{l}\text { Stavning og gram- } \\
\text { matik }\end{array}$ & $M$ & & & & & Lav & \\
\hline $\begin{array}{l}\text { Dansk, svensk og } \\
\text { norsk på mellem- } \\
\text { trinnet }\end{array}$ & $M$ & & & & & Нøj & Uklar \\
\hline Kim Fupz Aakeson & $M$ & & & & & $\mathrm{Høj}$ & Klar \\
\hline $\begin{array}{l}\text { Brødrene } \\
\text { Løvehjerte }\end{array}$ & $M$ & & & & & Høj & Uklar \\
\hline Lyrik & $M$ & & & & & Høj & Klar \\
\hline Skammerens datter & $M$ & & & & & Lav & \\
\hline Noveller & $M$ & & & & & Lav & \\
\hline
\end{tabular}




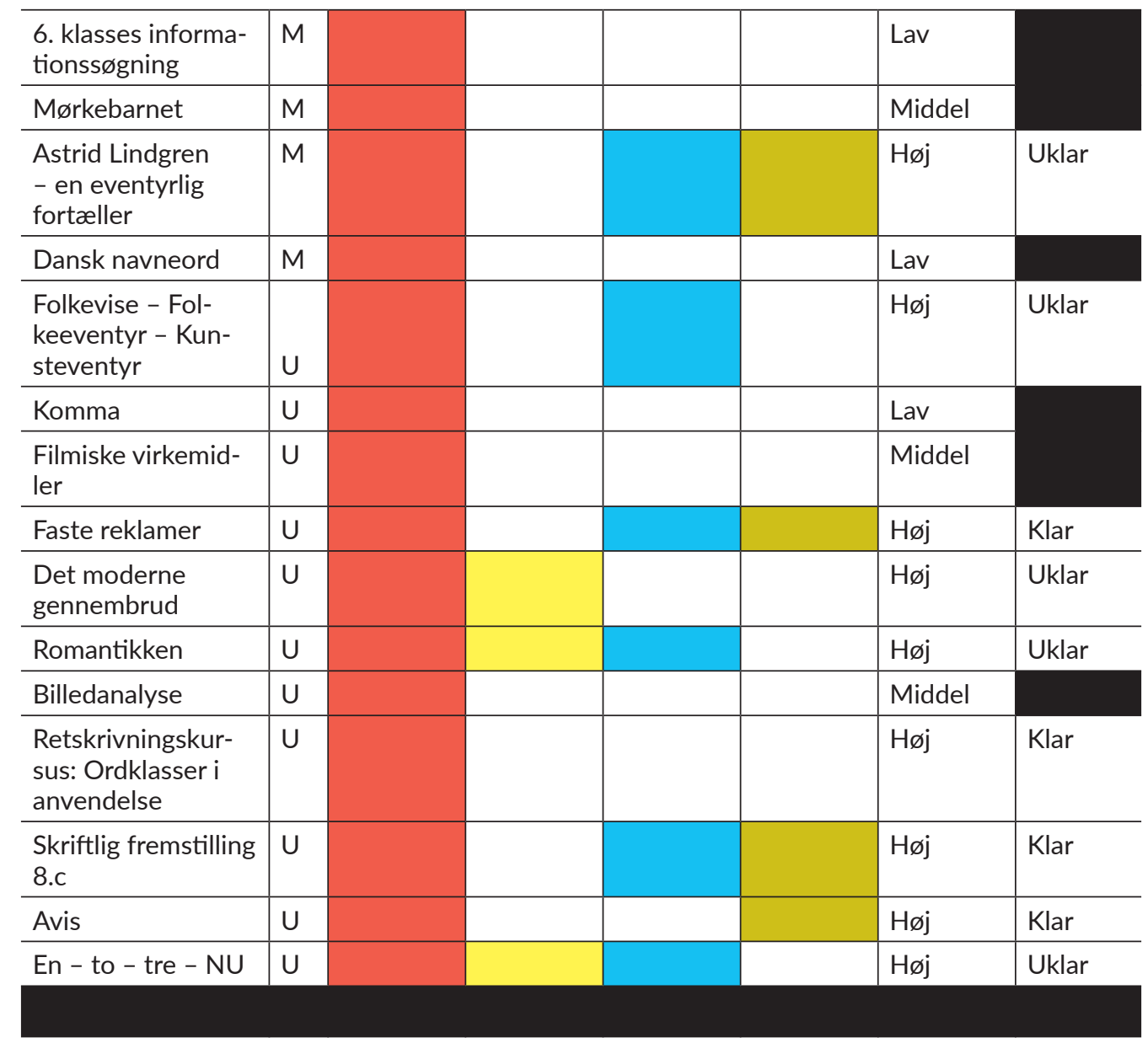

Analysen af fagdiskurser viser:

— 19 af de 37 forløb har et rent basisdanskfagligt fokus.

— Kun to forløb af de 37 indeholder ikke en basisdanskfaglig tilgang. Sagt på en anden måde: Basisdansk er på færde i 35 af de 37 forløb.

— I forløb, der kombinerer basisdansk med andre danskfaglige tilgange, ses oftest en kombination med identitetsdansk og $i$ en del tilfælde en kreativ opgave af en art.

— Kommunikationsdansk er kun i spil i 4 af de 37 forløb; det er forløb om hhv. faste reklamer, skriftlig fremstilling, avis samt en boganmeldelse i et litteraturforløb. I alle fire forløb sker det i kombination med basisdansk.

Den kreative dimension i forløbene har oftest mindre tyngde end de basis- og identitetsdanskfaglige elementer. Fx er der i forløbet $E n$ - to - tre - NU en cyklus, hvor eleverne, for hver bid læreren 
har inddelt bogen i, skal lave et resumé (basisdansk), skal besvare en række oftest lukkede spørgsmål (basisdansk) og dernæst vælge et afsnit, som gjorde særligt indtryk på dem og begrunde deres valg (identitetsdansk). Dette gør eleverne i alt seks gange. Herefter skal eleverne skriftligt opstille et persongalleri, dykke ned i romanens parallelforløb, overveje betydning af overskrifter og slutning samt tema, vurdere romanen og perspektivere til andre tekster (kombination af basisdansk og identitetsdansk). Til sidst i forløbet er en kreativ opgave, som er gengivet i Figur 6:

Figur 6. Kreativ opgave i et forløb domineret af basisdansk og identitetsdansk.

\section{KAPIIEL 8}

\section{EKSTRA OG KREATIV}

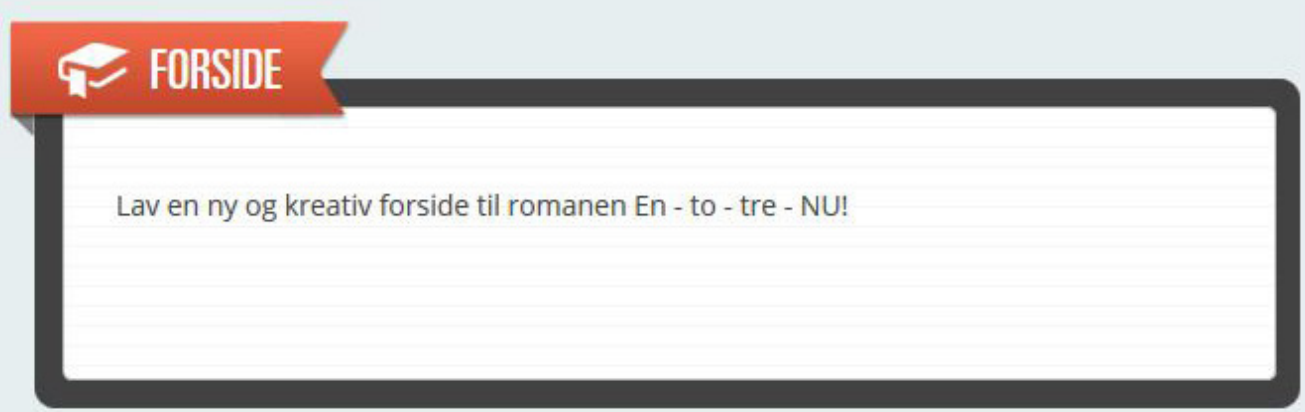

Sammenholder vi didaktiseringsgrad og fagdiskurs, er det påfaldende, at de 13 forløb som har lav didaktiseringsgrad også er rent basisfaglige. De resterende fem rent basisfaglige forløb har middel didaktiseringsgrad. Dermed er der en klar tendens til, at et snævert fokus på det basisdanskfaglige er forbundet med en lav didaktiseringsgrad og dermed også en uklar faglig intention. 


\section{Konklusion}

Vores fagdidaktiske analyse af lærerens produktion af didaktiske design viser, at halvdelen af lærerens forløb sker ud fra et basisdanskfagligt grundlag. Denne version af danskfaget repræsenterer kun en del af danskfaget og omfatter fx ikke elevernes oplevelse af litteratur som kilder til udvikling af personlig og kulturel identitet, deres personlige og alsidige sprogbrug eller deres åbne og analytiske indstilling til kulturens udtryksformer. Det er i stedet disse elementer, der giver faget eksistentiel og kulturel flyvehøjde. Dansk bliver ud fra en basisfaglig optik noget, man træner, og som bidrager til at udvikle grundlæggende færdigheder og viden om tekster og sprog. Spørgsmålet er, om denne version af danskfaget hænger sammen med, at læringsplatforme er 'gode' til at støtte organisering af basis-dansk-undervisning, hvor der arbejdes med lukkede og afgrænsede vidensformer, som kan målsættes, organiseres og trænes? Eller om basisdansk-diskursen grundlæggende har en dominerede rolle i forhold til de andre diskurser: Identitetsdansk, kreativitetsdansk og kommunikationsdansk? Disse spørgsmål kan vi ikke grundlæggende besvare på grundlag af vores analyse.

Vi begyndte denne artikel med at citere Ellen Krogh for det synspunkt, at når et fag bringes ind i nye kontekster, må det diskuteres og legitimere sig på ny. Den diskussion kan man håbe, at læringsplatformsarbejdet kan være med til at kvalificere, men vi er foreløbigt skeptiske over for, at læringsplatformen som didaktisk kontekst i sig selv kan være med til at udvikle nye faglige didaktiske design og innovativ undervisning. Endvidere er vi også skeptiske over for, at læringsplatformen i sin nuværende form kan understøtte læreres udvikling af didaktiske design med høj didaktiseringsgrad. Den danskfaglige praksis, som afspejles i de 37 forløb, er eksempler på interessante eksperimenter med at udvikle danskfaget i en ny praksiskontekst, men er, efter vores vurdering, endnu ikke eksempler, der kan bruges til at guide lærere ind i denne praksis. Hertil er lærerens fortrolighed med læringsplatformsmediet og dets didaktiske muligheder endnu for begrænsede. 


\section{Referencer}

Bundsgaard, J., Buch, B. \& Fougt, S. S. (2017). De anvendte læremidlers danskfag belyst kvantitativt. I J. Bremholm, J. Bundsgaard, S. S. Fougt, \& A. K. Skyggebjerg (red.), Loeremidlernes danskfag (s. 28-54). Aarhus: Aarhus Universitetsforlag.

Bundsgaard, J. \& Hansen, T. I. (2011). Holistic evaluations of learning materials. I J. R. Rodríguez, M. Horsley \& S. V. Knudsen (red.), Local, National and Transnational Identities in Textbooks and Educational Media: Ten International Conference on Research on Textbooks and Educational Media September 2009 Santiago de Compostela - Spain (s. 502-520). Santiago: IARTEM.

Coffey, A. (2014). Analysing documents. I U. Flick (red.), The SAGE handbook of qualitative data analysis (s. 367-380). Los Angeles: Sage.

Gee, J. P. (1990). Social Linguistics and Literacies: Ideology in Discourses. London: Routledge.

Graf, S., Gissel, S. \& Slot, M. (2018). Course designs in Meebook's course builder: analysis of 102 course designs. Loring Og Medier (LOM), 1O(18). DOI: 10.7146/lom.v10i18.97399

Hansen, J. J. (2006). Mellem design og didaktik: Om digitale loeremidler i skolen (ph.d.-afhandling). SDU, Faculty of Humanities, Institute for Design and Communication.

Hansen, J. J. (2010). Loeremiddellandskabet. Fra loeremiddel til undervisning. København: Akademisk Forlag.

Hansen, J. J. (2012). Dansk som undervisningsfag: perspektiver på didaktik og design. Frederiksberg: Dansklærerforeningen

Hansen, J. J. (2018). Læringsplatformsdidaktik - læringsplatforme som rammefaktor, didaktisk værktøj og læringssted. Learning Tech-Tidsskrift for loeremidler, didaktik og teknologi, (6).

Hansen, T. I. \& Bundsgaard, J. (2013). Kvaliteter ved digitale loeremidler og ved poedagogiske praksisser med digitale loeremidler. København: Ministeriet for Børn og Undervisning. Lokaliseret den 20. maj 2019 på: http://pure.au.dk/ portal/files/55476642/Hansen_Bundsgaard_2013._Effekter_af_digitale_l_ remidler._Rapport.ashx

Hansen, T. I. (2010). It og medier i et læremiddelperspektiv. KvaN, 30(86), 105116.

Krogh, E. (2011). Undersøgelser af fag i et fagdidaktisk perspektiv. I. E. Krogh \& F.V. Nielsen (red.), Cursiv 7: Sammenlignende fagdidaktik (s. 33-49). København: Danmarks Pædagogiske Universitetsskole, Aarhus Universitet. 
Learning Tech - Tidsskrift for læremidler, didaktik og teknologi Udgives af Læremiddel.dk

Learning Tech er et forskningstidsskrift, hvor alle artikler er forskerbedømt i form af dobbeltblindt peer review. Tidsskriftet bringer artikler, der rammer genstandsfeltet mellem læremidler, didaktik og teknologi, og hensigten er at spille en betydelig rolle som platform for den voksende skandinaviske læremiddelforskning.

\section{Redaktion}

Stig Toke Gissel, UCL Erhvervsakademi og Professionshøjskole (ansvarshavende redaktør)

Bettina Buch, Professionshøjskolen Absalon

Hildegunn Juulsgaard Johannesen, University College Syd

René Boyer Christiansen, Professionshøjskolen Absalon

Stine Reinholdt Hansen, UCL Erhvervsakademi og Professionshøjskole

Thomas R.S. Albrechtsen, University College Syd

\section{Redaktionssekretær}

Trine Ellegaard, UCL Erhvervsakademi og Professionshøjskole

\section{Temaredaktion}

Ane Qvortrup, Syddansk Universitet

Stig Toke Gissel, UCL Erhvervsakademi og Professionshøjskole

Morten Misfeldt, Aalborg Universitet

Jens Jørgen Hansen, Syddansk Universitet

\section{Design og grafisk tilrettelæggelse}

Trefold - grafisk design og kommunikation

\section{Tryk}

Narayana Press, Gylling

ISSN 2445-7981 (Tryk)

ISSN 2445-6810 (Online)

\section{Rettigheder}

(C) 2019 Læremiddel.dk og forfatterne

\section{Kontakt}

Læremiddel.dk, Niels Bohrs Allé 1, 5230 Odense M

https://learningtech.laeremiddel.dk

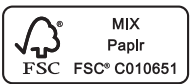

